\title{
Experimental transmission of green turtle fibropapillomatosis using cell-free tumor extracts
}

\author{
Lawrence H. Herbst ${ }^{1,2}$, Elliott R. Jacobson ${ }^{1,3}$, Rich Moretti ${ }^{5}$, Tina Brown ${ }^{5}$, \\ John P. Sundberg ${ }^{6}$, Paul A. Klein ${ }^{1,3,4}$

\begin{abstract}
${ }^{1}$ Department of Infectious Diseases and Comparative and Experimental Pathology (College of Veterinary Medicine), ${ }^{2}$ Division of Comparative Medicine, ${ }^{3}$ Department of Small Animal Clinical Sciences (College of Veterinary Medicine), and ${ }^{5}$ The Turtle Hospital, Hidden Harbor Marine Environmental Project, Marathon, Florida 33050, USA
\end{abstract} \\ ${ }^{4}$ Department of Pathology and Laboratory Medicine (College of Medicine), University of Florida, Gainesville, Florida 32610 , USA \\ ${ }^{6}$ The Jackson Laboratory, Bar Harbor, Maine 04609, USA
}

\begin{abstract}
Green turtle fibropapillomatosis (GTFP), characterized by multiple benign fibroepithelial tumors on the skin and eyes, has become a growing threat to green turtle Chelonia mydas populations worldwide. The cause of GTFP is unknown, but a viral etiology is suspected. This study investigated whether GTFP could be experimentally transmitted to young captive-reared green turtles using cell-free fibropapilloma extracts prepared from free-ranging turtles with spontaneous disease. Turtles raised from eggs collected from 4 separate clutches in the wild were assigned to 4 expermental groups and 1 control group. For each experiment a crude homogenate $(33 \% \mathrm{w} / \mathrm{v})$ was prepared from fibropapillomas removed from a free-ranging turtle with spontaneous disease. The crude tumor homogenates were freeze-thawed and centrifuged to yield cell-free extracts that were used (both filtered and unaltered) for inoculation. Recipients were inoculated by intradermal injection or by scarification; control turtles were not treated but were housed with treated turtles. Fibropapillomas developed in all 12 turtles receiving 3 of the 4 tumor extracts, and were first detected between 15 and $43 \mathrm{wk}$ post inoculation. Both filtered and unfiltered tumor extracts successfully induced tumor development. During the 10 and 12 mo monitoring periods, fibropapillomas did not develop in control turtles or in any turtles inoculated with the fourth tumor extract. Although 2 sets of experiments were performed $8 \mathrm{wk}$ apart, most of the tumors in both sets became evident simultaneously after water temperatures rose. Experimental tumors were histologically indrstinguishable from spontaneous fibropapillomas found in free-living turtles but lacked evidence of endoparasites. Scattered foci of epidermal degeneration were found in most sections of experimentally induced fibropapillomas and within some sections taken from donor turtles. Electron microscopy revealed virus-like particles conforming in size, morphology, and intranuclear location with herpesvirus. Negativestaining electron microscopy of transmission-positive tumor extracts failed to demonstrate intact virus particles. This study demonstrates that the etiology of GTFP is an infectious filterable subcellular agent. The herpesvirus identified in this study is 1 possible candidate for the etiology of GTFP.
\end{abstract}

KEY WORDS: Sea turtles Chelonia mydas - Fibropapilloma - Disease transmission

\section{INTRODUCTION}

Cutaneous papillomas, fibromas, and fibropapillomas were first described in green turtles Chelonia mydas over 50 yr ago (Lucké 1938, Smith \& Coates 1938, 1939). The first case was from an adult green turtle at the New York Aquarium (USA) that had been captured near Key West, Florida, USA and subsequent reports were from green turtles captured in Florida waters (Lucké 1938, Smith \& Coates 1938, Schlumberger \&
Lucké 1948). Green turtle fibropapillomatosis (GTFP) has subsequently been observed in many geographic locations around the world including the western Atlantic and Gulf of Mexico (Jacobson et al. 1989, Ehrhart 1991, Teas 1991), the Caribbean (Jacobson et al. 1989, Teas 1991, Williams et al. 1994, A. Meylan pers. comm.), the Pacific (Jacobson et al. 1989, MacDonald \& Dutton 1990, Balazs 1991, Limpus \& Miller 1994), and the Indian Ocean (Hendrikson 1958, J. Mortimer pers. comm.). In some well-monitored sites, the 
prevalence of GTFP has increased markedly since the 1980s. For example, in Hawaii, USA, the first confirmed case of GTFP was from a juvenile green turtle captured in Kaneohe Bay, Oahu in 1958. A survey of local fishermen conducted by Balazs (1991) indicated that GTFP was rare to non-existent prior to this. Since 1989 the prevalence of fibropapillomatosis in Kaneohe Bay has ranged from 49 to $92 \%$ (Balazs 1991).

These documented increases in prevalence coupled with the fact that GTFP is often fatal in severe cases have raised concerns about the potential impact of GTFP on the long-term stability of worldwide green turtle populations. These concerns have prompted efforts to identify the etiologic agent(s) and develop diagnostic reagents to monitor green turtle populatıons for exposure to this agent (Herbst 1994).

The etiology of green turtle fibropapillomatosis is unknown. Histologically, fibropapillomas are characterized by benign papillary epidermal hyperplasia supported on broad stalks of proliferating fibrovascular stroma (Lucké 1938, Smith \& Coates 1938, 1939, Schlumberger \& Lucké 1948, Jacobson et al. 1989. Harshbarger 1991, Aguirre et al. 1994, Williams et al. 1994). Agents known to cause similar proliferative cutaneous lesions in other species, including chemical carcinogens, ultraviolet light, oncogenic viruses, and metazoan parasites, have been proposed as possible causes of GTFP and have been reviewed by Sundberg (1991) and Herbst (1994).

The pattern of disease spread during GTFP outbreaks among captive green turtles is consistent with an infectious etiology (Jacobson 1981, Jacobson et al. 1989, Hoffman \& Wells 1991). The presence of spirorchid trematode ova in the vasculature of many fibropapillomas (Smith \& Coates 1939, Harshbarger 1984, Norton et al. 1990, Jacobson et al. 1991, Aguirre et al. 1994, M. Dailey pers. Comm., E. Greiner pers. comm.) has lead some pathologists to suggest that GTFP represents a fibroplastic reaction to trematode ova (Harshbarger 1984). A herpesvirus has been identified in foci of epidermal ballooning degeneration in some fibropapillomas (Jacobson et al. 1991); however, this virus has not been isolated and Koch's postulates have not been fulfilled. This paper presents the findings of a controlled transmission study designed to test the hypothesis that GTFP is caused by a virus. The results indicate that fibropapillomatosis in green turtles is an infectious disease caused by a filterable subcellular agent rather than a metazoan parasite.

\section{MATERIALS AND METHODS}

Experimental turtles. Green turtles to be used as recipients were obtained from the wild as eggs and raised in captivity. Five to 7 eggs from each of 4 green turtle nests made by different females within a $1 \mathrm{wk}$ period in August 1992 were collected on Melbourne Beach, Brevard County, Florida. Of the 4 nesting females, 3 were identified by flipper tags (S. Johnson pers. comm.). Following oviposition, each nest was marked and eggs were left in place until 1 to $10 \mathrm{~d}$ before their expected hatching dates (Rebel 1974). Eggs were then transported in separate plastic boxes filled with beach sand to a laboratory incubator $\left(28.5^{\circ} \mathrm{C}\right.$ and 95 to $100 \%$ relative humidity) where they remained through hatching, which occurred approximately 52 d post-oviposition (range 49 to $57 \mathrm{~d}$ ). Newly hatched green turtles were marked according to clutch by cutting a small notch in one of the marginal scutes. Hatchlings were maintained in the lab in plastic tubs filled with filtered sea water and fed a commercial pelleted diet (Reptomin ${ }^{3}$, TetraWerke, Melle, Germany) for approximately 2 wk. The babies were then transported by air to Marathon, Florida, where they were housed by clutch in 4 large fiberglass tanks (useable capacity 2400 l) on a continuous-flow system providing approximately 20 volume changes per day of filtered (PACFAB TA60 sand filter) Florida Bay water. The turtles were fed floating trout chow (Purina, St. Louis, MO, USA) ranging from 1.5 to $1.75 \%$ body weight per day, the amount adjusted to prevent obesity, provide for moderate growth, and minimize cannibalism. The filters were back-flushed daily. Tanks were vacuumed weekly and thoroughly cleaned monthly. Water temperatures, $\mathrm{pH}$, and salinity (specific gravity) were monitored and recorded weekly. Twenty turtles (5 from each clutch) were raised until they were between 9 and 11 mo old before experiments were begun.

Fibropapilloma donor turtles. Four free-ranging juvenile green turtles with multiple cutaneous fibropapillomas that stranded or were collected in Florida Bay or the lower Florida Keys were used as tumor donors in 2 sets of replicate transmission experiments carried out $8 \mathrm{wk}$ apart. Fibropapillomatosis was severe enough in these turtles to justify their removal from the wild for rehabilitation. General anesthesia was induced in each donor turtle with a mixture of isoflurane (Aerrane ${ }^{\text {B }}$, Anaquest, Madison, WI, USA) and nitrous oxide in oxygen delivered by mask and then by endotracheal tube. Once anesthetized, the turtles were draped and tumors were prepared by washing with copious amounts of sterile saline and scrubbing with a sterile brush. All cutaneous tumors were excised and incisions were closed with 2.0 nylon suture material (Dermalon ${ }^{\circledast}$, American Cyanamid, Danbury, CT, USA). Highly arborizing fibropapillomas with intact epithelium were selected for use in the transmission experiments. Ulcerated and necrotic masses were discarded. 
Each tumor was cut into quarters. Representative sections were taken from each quarter and either fixed in $10 \%$ buffered formalin or immersed in OCT medium (Tissue-Tek ${ }^{\circ}$, Miles Inc, Elkhart, IN, USA) and frozen in liquid nitrogen. A portion of each mass was retained for tissue culture studies. The remaining pieces were placed in a sterile cup, weighed, and stored on dry ice until processing.

Preparation of cell-free tumor homogenates. Pooled fibropapilloma fragments from each donor were thawed and minced with a sterile scalpel and scissors and ground in a blender (Osterizer ${ }^{\oplus}$, Sunbeam-Oster, Schaumburg, IL, USA) in chilled sterile saline. The ground tumor was further homogenized in Ten Broeck glass tissue homogenizers (Pyrex, Corning, NY, USA) on ice. This homogenate was frozen on dry ice and kept frozen for 15 min before being thawed and ground a second time. A second freeze-thaw cycle was then performed. Sufficient sterile saline was added during the homogenization process to yield a final $33 \% \mathrm{w} / \mathrm{v}$ crude homogenate. This crude homogenate was first centrifuged in a clinical centrifuge at $500 \times g$ for $10 \mathrm{~min}$ to sediment large debris and the supernatant was collected. Centrifugation of the pellet was repeated once and the supernatant added to that previously collected. The supernatant was then centrifuged at $10000 \times g$ for 10 to $15 \mathrm{~min}$ in a Savant microcentrifuge to pellet cells and debris. Samples of this supernatant were examined microscopically to confirm the absence of intact cells. Approximately half of the cell-free supernatant was filtered through a $0.45 \mu \mathrm{m}$ syringe tip filter $\left(\right.$ Acrodisc $^{\circledR}$, Gelman Sciences, Ann Arbor, MI, USA) to remove contaminating bacteria and any remaining intact cells. The other half of the cellfree supernatant was used as an unfiltered extract. The final centrifugation pellets and aliquots of unfiltered and filtered supernatants were frozen in liquid nitrogen and stored at $-150^{\circ} \mathrm{C}$ in a liquid nitrogen freezer.

Experimental treatments. Prior to treatment each recipient was manually restrained and a $1 \mathrm{ml}$ blood sample was collected from the dorsal cervical sinus for plasma banking (Owens \& Ruiz 1980). In each replicate experiment, tumor extract from 1 donor turtle was used to treat 1 recipient from each clutch. Treatments included intradermal injections using a $0.5 \mathrm{ml}$ insulin syringe with a 27 gauge needle into the upper eyelid (0.1 ml), proximal margin of a large scale on the palmar surface of the front flipper $(0.2 \mathrm{ml})$, proximal margin of a large scale on the dorsal surface of the rear flipper $(0.2 \mathrm{ml})$, and instillation into scarified skin on the dorsum of the neck $(0.1 \mathrm{ml})$ and shoulder $(0.1 \mathrm{ml})$. Skin was scarified with an 18 gauge needle and the inoculum was worked into the tissue by multiple needle pricks with a 25 gauge needle and allowed to air dry for at least $15 \mathrm{~min}$ before turtles were returned to water. All treated turtles received inoculations of filtered tumor extract on the right side of the body. In addition half of the treated turtles received sterile saline (sham) inoculations and half received unfiltered extract inoculations at comparable sites on the left side of the body. On the neck, turtles received either unfiltered or filtered tumor extract. One turtle from each clutch was kept as a control (sentinel). Sentinel turtles received no inoculations but were maintained in the same tanks as their treated clutch-mates to control for waterborne or contact transmission by the putative infectious agent.

Treated turtles were held and observed for 12 mo following inoculations. Turtles were visually inspected daily and palpated weekly for development of inflammation or masses. Observations were recorded weekly. Blood samples were collected at various times during the monitoring period.

Histopathology. Biopsies of normal skin and putative GTFP lesions were collected, using a $6 \mathrm{~mm}$ biopsy punch or scalpel blade under $2 \%$ lidocaine local anesthesia, and fixed in neutral buffered $10 \%$ formalin for histopathologic examination.

Transmission electron microscopy. Specimens for electron microscopy were punched from formalin fixed, paraffin embedded fibropapillomas, post-fixed in osmium tetroxide, and embedded in Spurr's resin. Ultrathin sections were placed on copper grids and stained with uranyl acetate and lead citrate and examined on an electron microscope.

Negative-staining electron microscopy. Samples of $0.45 \mu \mathrm{m}$ filtered tumor extracts that had successfully transmitted GTFP were examined for the presence of virus-like particles as follows. First, $10 \mu$ samples of filtered tumor extract were applied to carbon-coated 400 mesh copper grids and allowed to adsorb for 10 to $30 \mathrm{~s}$. The grids were drained of excess liquid with a filter paper wick and then immediately floated on a drop of $2 \%$ aqueous uranyl acetate for $30 \mathrm{~s}$. The grids were drained of excess fixative and allowed to air dry before examination in the electron microscope. Second, $1 \mathrm{ml}$ of filtered tumor extract was centrifuged at $12000 \times g$ for $20 \mathrm{~min}$. The clarified supernatant was then centrifuged at $100000 \times g$ for $2 \mathrm{~h}$ in an Airfuge A-100/18 rotor (Beckman Instruments, Fullerton, CA, USA). The pellet was resuspended in $40 \mu$ distilled water and aliquots were adsorbed to carbon-coated 400 mesh copper grids and prepared for electron microscopy as described above.

\section{RESULTS}

Table 1 summarizes information for each of the 4 donor turtles used in this study. The donor turtles were juveniles ranging from 35 to $59 \mathrm{~cm}$ straight 
Table 1 Chelonia mydas. Free-ranging green turtles with cutaneous fibropapillomatosis used as fibropapilloma donors

\begin{tabular}{|c|c|c|c|c|}
\hline Identity & $\begin{array}{l}\text { Capture/stranding } \\
\text { date (1993) }\end{array}$ & $\begin{array}{c}\text { Location } \\
\text { (Florida, USA) }\end{array}$ & $\begin{array}{l}\text { Straight } \\
\text { carapace length } \\
(\mathrm{cm})\end{array}$ & $\begin{array}{c}\text { Wet wt of pooled } \\
\text { fibropapillomas used } \\
\text { in extract preparation }(\mathrm{g})\end{array}$ \\
\hline Donor 1 'Flamingo' & 28 Jun & $\begin{array}{l}\text { Florida Bay, } \\
\text { Everglades National Park }\end{array}$ & 35.6 & 9.0 \\
\hline Donor 2 'Everglades' & 30 Jun & $\begin{array}{l}\text { Florida Bay, } \\
\text { Everglades National Park }\end{array}$ & 61.4 & 19.0 \\
\hline Donor 3 'Pappy' & $25 \mathrm{Aug}$ & Florida Keys, Stock Island & 58.5 & 26.3 \\
\hline Donor 4 'Coastie' & 21 Aug & $\begin{array}{l}\text { Florida Keys, } \\
\text { Bahia Honda Bridge }\end{array}$ & 59.3 & 15.4 \\
\hline
\end{tabular}

carapace length. Each had multiple cutaneous fibropapilionas ıanyiny in size from a few milimineters to over $9 \mathrm{~cm}$ in diameter involving the axillary and inguinal regions, front and rear flippers, neck, and eyelids. Two turtles, donors 2 (Everglades) and 4 (Coastie), were unable to maintain neutral buoyancy and floated high in the water. Both subsequently died and were found on necropsy to have multiple pale firm nodules (fibromas) in visceral organs including lungs, kidney, liver, and heart. The other 2 donor turtles were surgically treated and 1 has been released. Between 9.0 and $26.3 \mathrm{~g}$ of cutaneous fibropapillomas from each donor were used to prepare tumor extracts for use in transmission experiments.

\section{Transmission experiments}

Recipient turtles had grown to approximately $25 \mathrm{~cm}$ straight carapace length and were either 9 mo (groups 1 and 2) or 11 mo old (groups 3 and 4) when used in these experiments. Flipper and tail biting became a problem as turtles grew and 1 of the control turtles died from wound infection before the experiments could be initiated. Biting was reduced by altering the feeding schedule from single to multiple feedings per day.

Four independent transmission experiments were conducted on the following dates: 6 and 7 July 1993 (groups 1 and 2 using homogenates from donors 1 and 2 respectively), and 3 and 4 September 1993 (groups 3 and 4 using homogenates from donors 3 and 4 respectively). Table 2 shows the results of inoculations with filtered tumor extracts after 10 and 12 mo respectively. The 3 control (sentinel) turtles did not develop spontaneous tumors during this period. All 12 turtles inoculated with tumor extracts from donors 1,2, and 3 developed tumors at 1 or more injection sites. The 4 turtles in group 4 , which received tumor extract from donor 4 , did not develop tumors. Tumors developed only at sites that were inoculated with GTIP extracts (Fig. 1). Tumors did not develop at sham-inoculated sites or at any uninoculated sites. Although several turtles incurred bite wounds on rear flippers and tails, fibropapillomas did not develop at these locations. Table 3 lists the frequencies of fibropapilloma development by the type of inoculum and route of inoculation. Filtered GTFP extracts were no more successful than unfiltered extracts in inducing tumor development $158 \%$ of injection sites and $17 \%$ of scarification sites in 16 turtles versus $42 \%$ of injection sites and $19 \%$ scarification sites in 8 treated turtles). The differences in percent success between filtered and unfiltered extracts were not statistically significant $\left(\chi^{2}, p>0.10\right)$. On the other hand, sites injected intradermally were more likely to develop tumors than scarification sites $\left(\chi^{2}, p<0.05\right)$

Table 2. Chelonia mydas. Fibropapilloma development at inoculation sites in green turtles treated with filtered cell-free fibropapilloma extracts. Expt no. corresponds to donor no. + : tumor growth at 1 or more inoculation sites; -: no tumor growth at any treatment site. Data in parentheses: the number of anatomic sites where tumors developed over the number that were inoculated with $0.45 \mu \mathrm{m}$ filtered cell-free tumor extracts. Sixteen turtles were inoculated by injection or scarification at 4 or 5 sites on the right side of the body with filtered extracts prepared from 4 donor turtles with spontaneous tumors. The control group was not inoculated. In addition, 6 of 8 turtles (2 each from Expts 1,2, and 3) that were inoculated with unfiltered extract at comparable sites on the left side of the body developed tumors at 1 or more sites while the remaining 2 turtles from Expt 4 did not

\begin{tabular}{|lllllc|}
\hline Recipients & Expt 1 & Expt 2 & Expt 3 & Expt 4 & Control \\
\hline Clutch A $+(2 / 4)$ & $+(2 / 5)$ & $+(3 / 5)$ & $-(0 / 4)$ & - \\
Clutch B $+(2 / 4)$ & $+(2 / 5)$ & $+(4 / 4)$ & $-(0 / 5)$ & na \\
Clutch C $+(1 / 5)$ & $+(2 / 4)$ & $+(3 / 5)$ & $-(0 / 4)$ & - \\
Clutch D $+(3 / 5)$ & $+(3 / 4)$ & $+(3 / 4)$ & $-(0 / 5)$ & - \\
ana: this control turtle died before experiments were begun \\
\hline
\end{tabular}



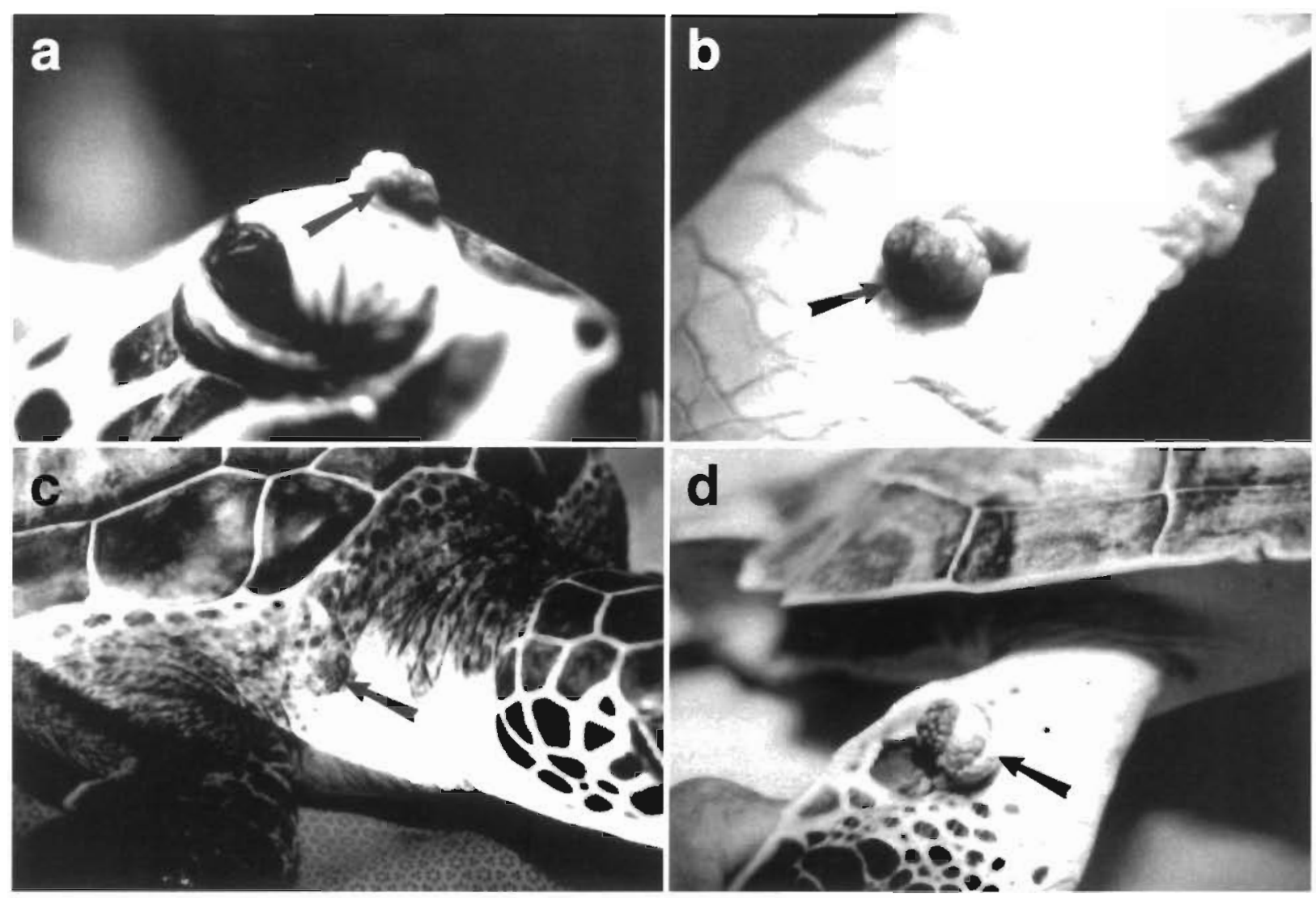

Fig. 1. Chelonia mydas. Experimentally induced cutaneous fibropapillomas in green turtles. Representative tumors (arrows) were chosen to illustrate site-specific development and gross appearance at the time of biopsy. Tumors developed at 1 or more inoculation sites in 12 of 16 recipient turtles from 3 of 4 independent transmission experiments. (a) Recipient C-3 with sessile, verrucous tumor on right upper eyelid induced by intradermal injection of filtered tumor extract. (b) Recipient $\mathrm{C}$ - 2 sessile, smooth tumor on right front flipper induced by intradermal injection of filtered tumor extract. (c) Recipient B-3 sessile, verrucous tumor on right shoulder induced by scarification with filtered tumor extract. (d) Recipient C-3 pedunculated, verrucous tumor on right rear flipper induced by intradermal injection of filtered tumor extract

\section{Time to tumor development}

Fig. 2 shows the time course of tumor development for individual turtles during this study. Earliest indications of tumor development were identified as slightly raised epidermal swellings ranging from 0.5 to $8 \mathrm{~mm}$ maximum diameter. The earliest tumors were detected at $15 \mathrm{wk}$ post-inoculation in 2 turtles from replicate 3. The time lag between inoculation and observation of the first tumors to develop on individual turtles ranged from 14.6 to $43.4 \mathrm{wk}$ (mean $26 \pm 8.8 \mathrm{wk}$ ). The average lag time for first tumor detection was $8 \mathrm{wk}$ longer for the 8 turtles in the first set of replicates (July) (mean $28.6 \pm 8.4 \mathrm{wk}$ ) than for the 4 turtles in the second set (September) (mean 20.6 $\pm 7.7 \mathrm{wk}$ ), although this difference was not statistically significant (Mann-Whitney $U$-test, 2 -tailed, $0.05<\mathrm{p}<0.10$ ). The average mean tumor detection time (averaged for all tumors on each individual) was $6.8 \mathrm{wk}$ longer for the 8 turtles in the first set (mean $33.4 \pm 5.2 \mathrm{wk}$ ) than for those in the second set (mean $26.6 \pm 4.3 \mathrm{wk}$ ) and this difference was statistically significant (Mann-Whitney $U$-test, 2 -tailed, $p<0.05$ ). This difference roughly corresponds to the $8 \mathrm{wk}$ gap between sets of replicate experiments and suggests that tumors tended to appear synchro-

Table 3. Chelonia mydas. Frequency of fibropapilloma development at injection and scarification sites in recipient green turtles. 0.1 to $0.2 \mathrm{ml}$ of inoculum injected intradermally at 3 sites (upper eyelid, front, and rear flippers) on each turtle; scarification sites: $0.1 \mathrm{ml}$ of inoculum applied to scarified skin on neck and shoulders

\begin{tabular}{|c|c|c|}
\hline $\begin{array}{l}\text { Inoculum } \\
\text { (tumor extracts) }\end{array}$ & Injection sites & Scarification sites \\
\hline Unfiltered & $10 / 24(42 \%)^{d}$ & $3 / 16(19 \%)$ \\
\hline Filtered & $28 / 48 \quad(58 \%)$ & $4 / 24 \quad(17 \%)$ \\
\hline
\end{tabular}




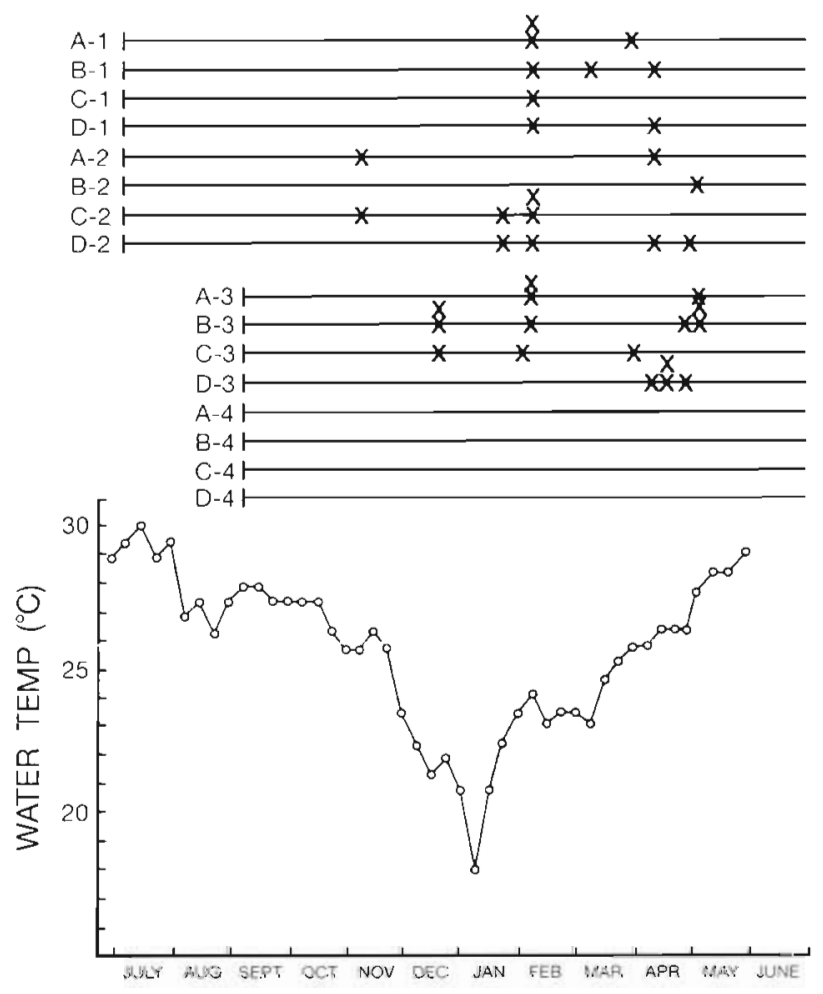

Fig. 2. Chelonia mydas. Time course for experimental fibropapilloma induction in the green turtle. Horizontal lines (A-1 to D-4) represent the observation periods for each recipient turtle beginning with the dates of their inoculation with tumor extract. Dates on which tumors were first detected are indicated. The graph indicates the fluctuation in water temperature (recorded weekly) during the course of this experiment

nously. The majority of fibropapillomas (29 out of 36) were initially detected between early February and May regardless of when turtles were inoculated. Only 4 turtles had tumors develop within the first 4 mo postinoculation. During the course of the experiment water temperatures ranged from $30^{\circ} \mathrm{C}$ in the summer to $17.5^{\circ} \mathrm{C}$ in the winter and were lowest (below $21^{\circ} \mathrm{C}$ ) from December through January (Fig. 2). Salinity and $\mathrm{pH}$ remained constant ( 1.027 spec grav. and 8.2 respectively). The onset of colder water temperatures in December appeared to retard growth rates of early tumors. A similar effect on subclinical tumors could synchronize their appearance with the return to warmer water temperatures

\section{Histopathology}

Thirty-three experimentally induced fibropapillomas from 11 recipient turtles were biopsied between 1 and 27 wk following detection. Lesions were raised, sessile or polypoid masses with verrucous or smooth surfaces and ranged from 0.5 to $2 \mathrm{~cm}$ in diameter when biopsied (see Fig. 1). Tumors consisted of epidermal hyperplasia supported by arborizing proliferating fibrovascular stroma (Fig. 3). Hyperplastic epidermis was between. 7 and 15 cell layers thick. Most of the hyperplasia was in the stratum spinosum and cells in this layer were hypertrophic. There was extensive proliferation of fibroblasts within the papillary layer of the dermis. The dermis was hypercellular with fine collagen bundles arranged in an irregular pattern. Cells in the dermis were well-differentiated spindle-shaped cells with a fine chromatin pattern. Perivascular mononuclear cell infiltrates were observed within the deeper layers of the dermis in most sections. No trematode ova were observed within any sections. The histologic features of these induced lesions were consistent with spontarieouis green tiritle fibupapiliumas jucobson et ai. 1989). In addition, scattered foci of ballooning degeneration were observed within the spinous layer of the epidermis in sections of 24 tumors (72\%) from 10 of the 11 turtles (Fig. 4A). Degenerating keratinocytes were hypertrophic and vacuolated. In some foci many epidermal cells contained eosinophilic intranuclear inclusions (Fig. 4B) while in others, most cells had pyknotic nuclei.

\section{Transmission electron microscopy}

Intranuclear inclusions within degenerating keratinocytes contained virus-like particles ranging from 80 to $90 \mathrm{~nm}$ in diameter These intranuclear particles were in various stages of assembly ranging from empty capsids to intact nucleocapsids with electron dense cores (Fig. 5A). These immature particles were observed in the process of budding through the nuclear membrane (Fig. 5B). Mature enveloped particles in the cytoplasm measured 110 to $125 \mathrm{~nm}$ (Fig 5C).

\section{Negative staining electron microscopy}

No virus-like particles could be demonstrated in samples of transmission positive tumor extracts or in ultracentrifuge pellets prepared from $1 \mathrm{ml}$ aliquots of these extracts by negative staining electron microscopy.

\section{DISCUSSION}

Fibropapillomas were induced in 12 healthy captivereared juvenile green turtles using filtered cell-free extracts prepared from fibropapillomas collected from 3 out of 4 donors with spontaneous disease. These results provide the first experimental evidence that 
Fig. 3. Chelonia mydas. Experimentally induced fibropapilloma in the green turtle showing characteristic benign epidermal hyperplasia on broad fibrovascular stalks. These experimental lesions did not contain spirorchid trematode eggs. $H \& E_{1} \times 49$, scale bar $=200 \mu \mathrm{m}$

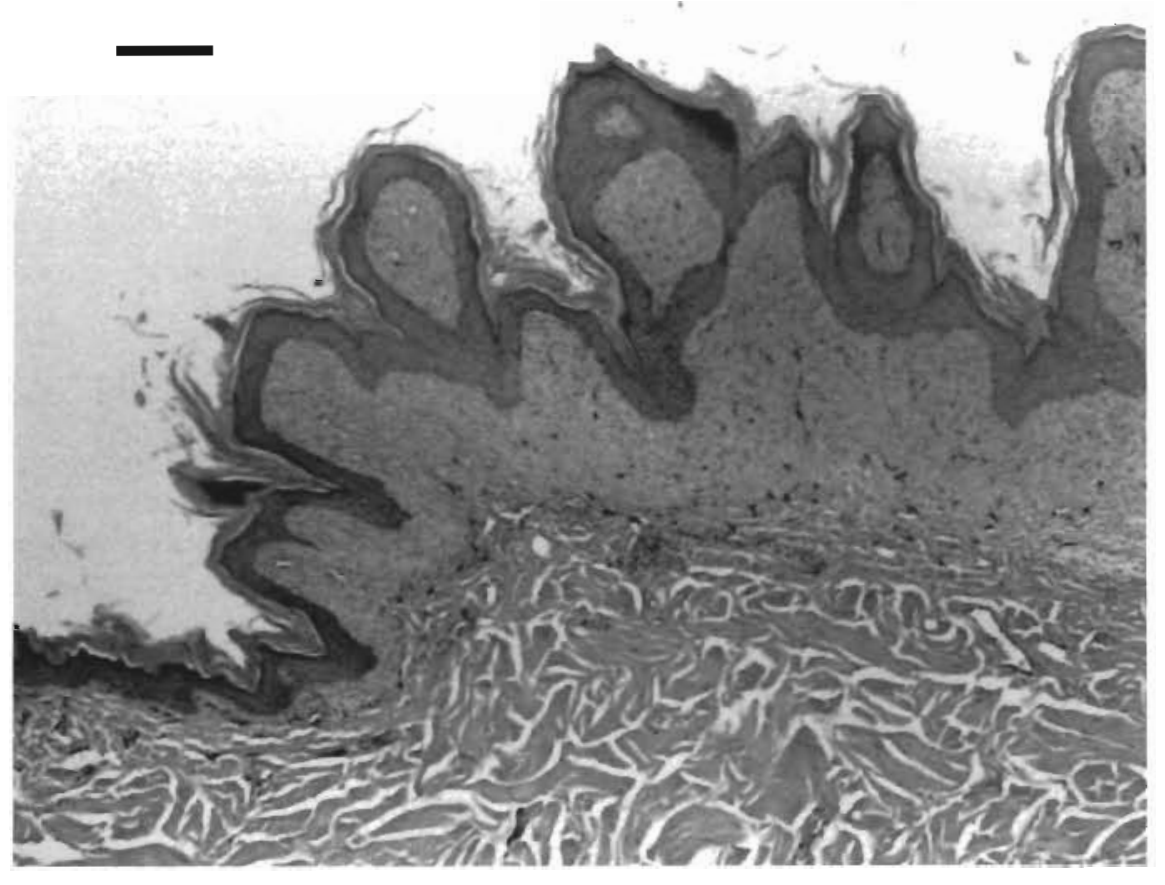

GTFP is caused by an infectious agent under $0.45 \mu \mathrm{m}$ in size, most likely a virus. The filtration step eliminated most bacteria (except mycoplasmas) as possible etiologic agents.

A possible etiologic role for trematode ova was also excluded by the filtration step and by the absence of trematode ova within the 33 experimentally induced fibropapillomas. These observations are in agreement with earlier experiments, in which suspensions of spirorchid trematode eggs injected intradermally at several anatomic sites in 3 captive-reared yearling turtles failed to induce tumors after more than 1 yr of observation (Herbst et al. 1994). Taken together these findings rule out the direct involvement of trematode eggs in the pathogenesis of GTFP.

Histologically the experimentally induced tumors were consistent with published descriptions of naturally occurring GTFP (Lucké 1938, Smith \& Coates 1938, 1939, Schlumberger \& Lucké 1948, Jacobson et al. 1989, Harshbarger 1991, Aguirre et al. 1994, Williams et al. 1994). However, in addition, scattered foci of epidermal ballooning degeneration were observed in $24(72 \%)$ of the experimentally induced tumors. These areas contained herpesvirus-like particles that are similar in size and morphology to those described by Jacobson et al. (1991). Similar areas of epidermal change were found in at least 1 of 5 tumor biopsies examined from the 3 transmission positive donor turtles. Except for Jacobson et al. (1991), previ- ous surveys of GTFP biopsy material for light and electron microscopic evidence of virus infection have yielded negative results (Smith \& Coates 1938, Jacobson et al. 1989, Aguirre et al. 1994).

The significance of this association of herpesvirus with spontaneous and experimental GTFP remains unclear. Previously reported herpesviruses of green turtles include the agent of grey patch disease (Rebell et al. 1975) and a herpesvirus associated with respiratory disease (Jacobson et al. 1986a). Because herpesviruses have a tendency to colonize tumors and tissues of debilitated animals it is possible that their presence in fibropapillomas represents a secondary infection unrelated to the primary disease process. On the other hand, herpesviruses have been associated with or shown to cause neoplasia in several other species including cutaneous papillomas in green lizards (Raynaud \& Adrian 1976), African elephants (Jacobson et al. 1986b), carp (Sano et al. 1985, Hedrick et al. 1990), and several salmonid species (Kimura et al. 1981a, b, c, Sano et al. 1983, Yoshimizu 1987), Lucké renal adenocarcinoma in frogs (Mckinnell 1984), Marek's disease in chickens (Powell 1985), lymphoma in new world primates (Trimble \& Desrosiers 1991), and Burkitt's lymphoma in humans (Henle \& Henle 1985). We cannot conclude that this herpesvirus is the etiologic agent of GTFP until it has been isolated and proven to be oncogenic in transmission experiments. 


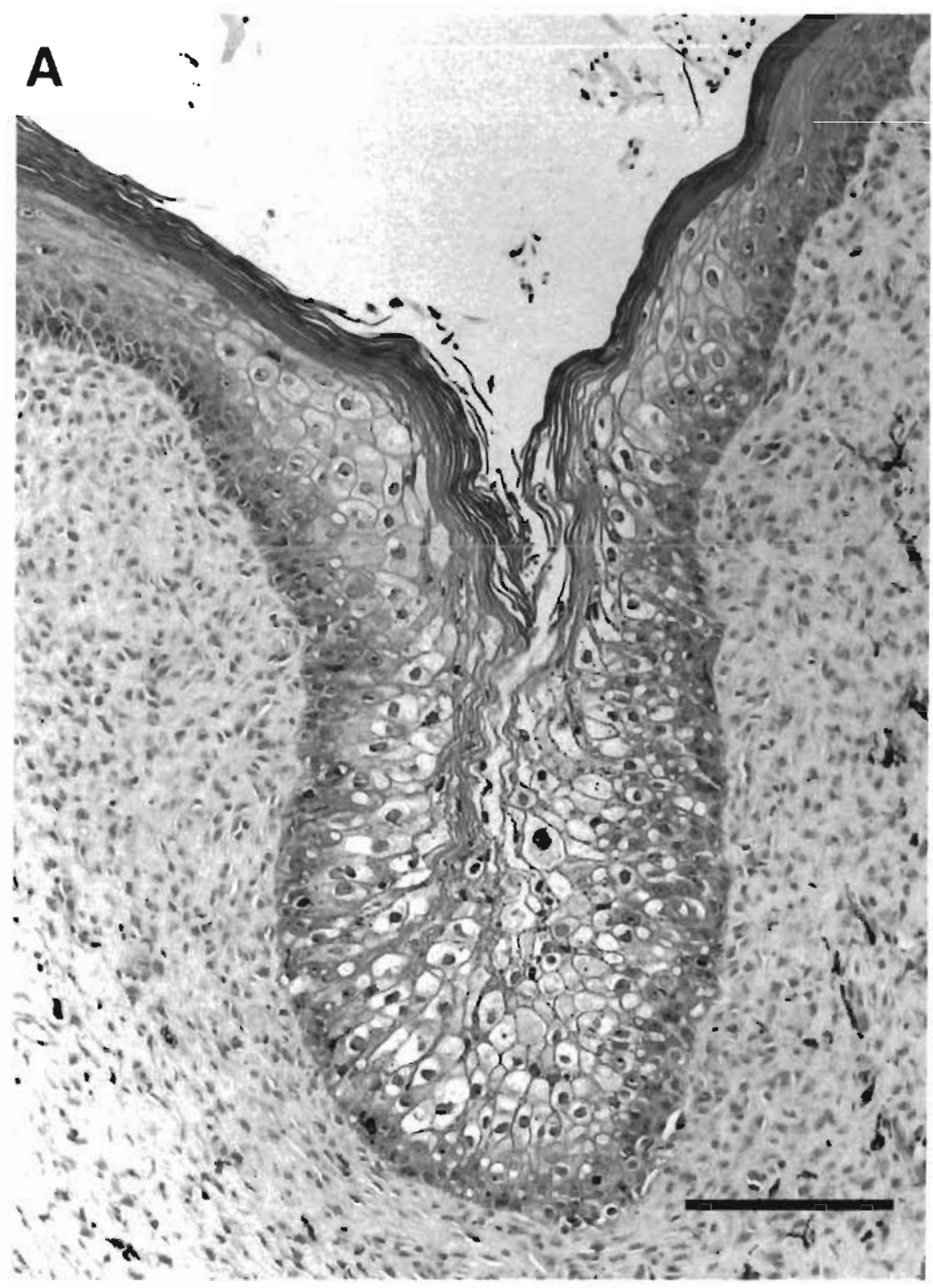

Fig. 4. Chelonia mydas. Experimentally induced fibropapilloma in the green turtle. (A) Focal ballooning degeneration in the epidermis. $\mathrm{H} \& \mathrm{E}, \times 120$, scale bar $=200 \mu \mathrm{m}$ (B) Higher magnification showing intranuclear inclusions within degenerating keratinocytes. $\mathrm{H} \& \mathrm{E}, \times 240$, scale bar $=100 \mu \mathrm{m}$

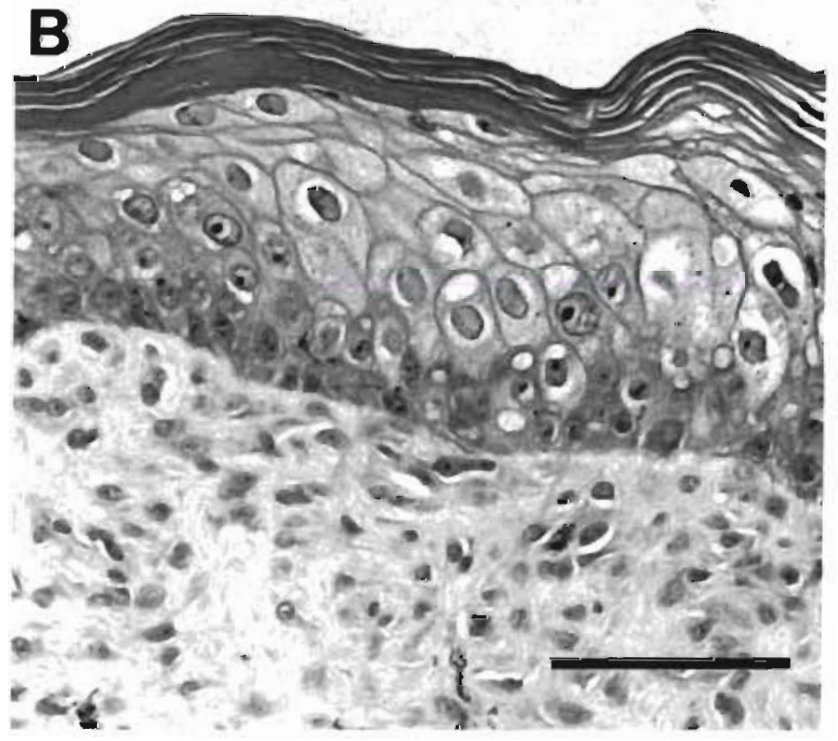

Meanwhile, other virus types that have been associated with or shown to cause proliferative skin lesions in vertebrates must be included on the list of potential etiologic agents for GTFP. For example, papillomaviruses (papovaviridae) cause papillomas, fibromas, and fibropapillomas in many vertebrate species (Sundberg 1987) and have been observed in hyperplastic skin lesions of Bolivian side-necked turtles (Jacobson et al. 1982). In addition to herpesvirus, papovavirus-like particles have been found in papillomas of green lizards (Raynaud \& Adrian 1976, Cooper et al. 1982). A polyomavirus (papovaviridae) has been associated with cutaneous neoplasia in hamsters (Graffi et al. 1968). Poxviruses cause proliferative skin lesions in squirrels (Hirth et al. 1969, O'Connor et al. 1980), rabbits (Shope 1932, Pulley \& Shively 1973), and primates (Behbehani et al. 1968). Retroviruses have been associated with 


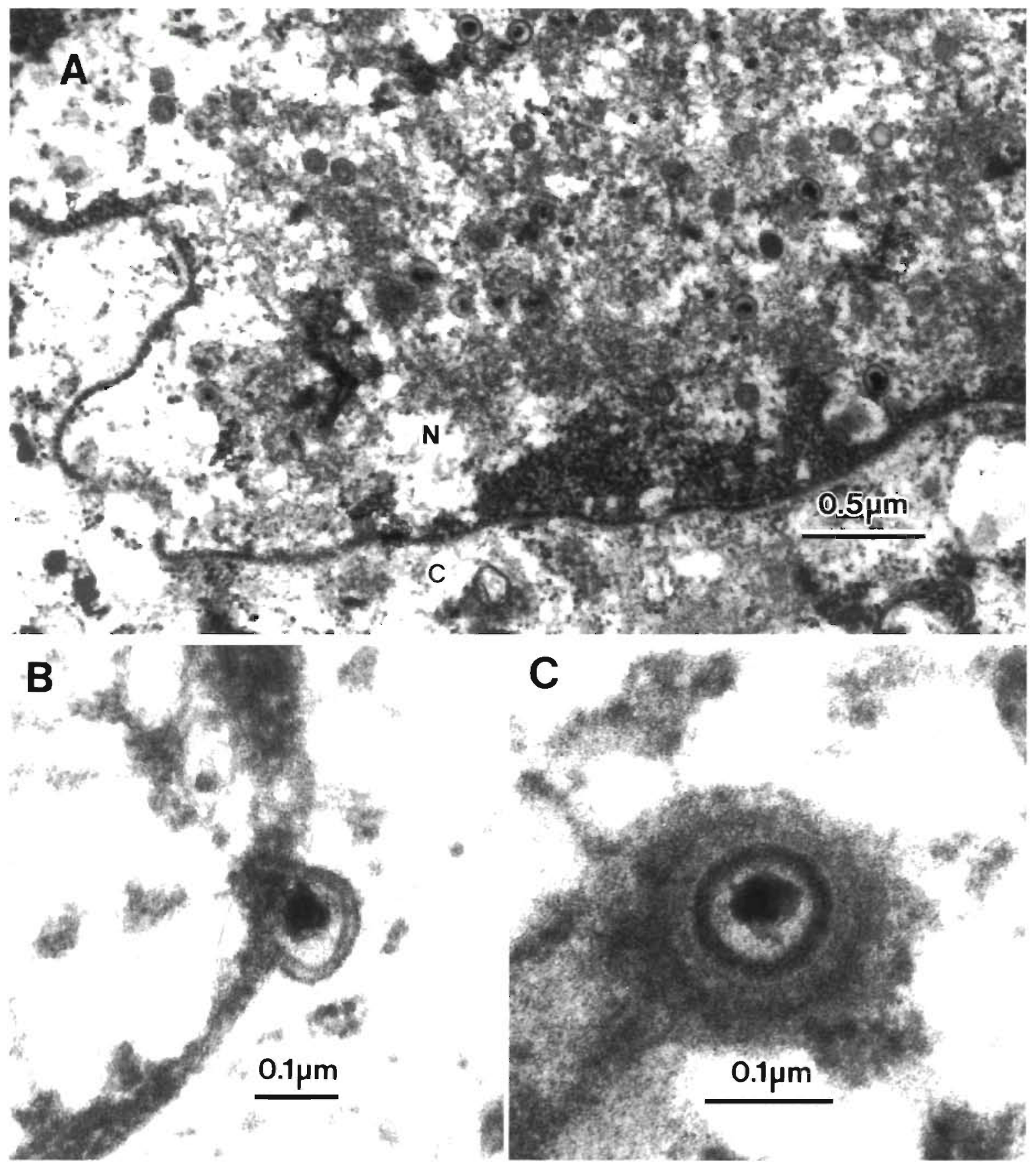

Fig. 5. (A) Herpesvirus-like particles from Chelonia mydas fibropapillomas, in various stages of development within the nucleus $\mathrm{N}$ : nucleus; C: cytoplasm. Both empty capsids and complete nucleocapsids containing electron dense cores can be seen. $\times 37000$ (B) Virion budding through the nuclear membrane. $\times 128000$. (C) Mature enveloped virion within the cytoplasm. $\times 195000$

fibromas and sarcomas in several species including walleyes (Martineau et al. 1991), angelfish (FrancisFloyd et al. 1993), cats (Hardy 1985), and non-human primates (Gardner \& Marx 1985, Tsai et al. 1990).

We attempted to identify virus particles in samples of transmission-positive cell-free tumor extracts using negative staining electron microscopy. However, our initial studies have been unsuccessful. One explanation is that the agent was destroyed during prolonged storage or during thawing and sample preparation. Enveloped viruses such as herpesviruses and retroviruses are more sensitive to storage and processing conditions and although crude extracts were stored at $-150^{\circ} \mathrm{C}$ we did not attempt to protect viruses from 
proteolytic enzymes. A second possibility is that the concentrations of intact viral particles within extracts were below the detection limits of the method. Successful detection by negative staining electron microscopy requires approximately $10^{6}$ to $10^{9}$ virus particles per ml (Doane 1992). We suspect that this was the case because, for example, the herpesvirus described in this study was found in scattered foci within a very small percentage of epidermal cells. Similarly, papillomavirus vegetative replication occurs sporadically in only the most superficial terminally differentiated epidermal cells of a wart (Howley 1990). A third possibility is that the agent that causes GTFP is present in tumors primarily as episomal genetic material which is infectious under experimental conditions as shown for severai papovaviruses, including hamster polyomavirus (Graffi et al. 1969) and cottontail rabbit papillomavirus (Ito \& Evans 1961, Brandsma \& Xiao 1993). Several oncogenic viruses, including papillomaviruses (Howley 1983) and retroviruses (Benjamin \& Vogt 1990), cause neoplastic lesions in tissues that are not permissive to vegetative viral replication. Thus tumors develop and intact viral genomes are found within transformed cells but virions are not produced. Finally, another but less probable explanation for our inability to detect virus particles in tumor extracts is that GTFP is caused by a sub-cellular infectious agent that is not detectable by electron microscopy such as a viroid (infectious nucleic acid) or prion (infectious protein) (Cohen et al. 1994).

This study was limited to 20 recipient turtles because the green turtle is an endangered species. The experimental design was a $4 \times 5$ matrix that assigned recipient turtles from 4 separate clutches into 4 experimental groups and 1 control group. This design was chosen to minimize the chances of transmission failure due to donor factors such as the stage of tumor progression and the infectious dose of the putative agent, or recipient factors such as innate or acquired resistance and prior disease exposure. Turtles within a clutch were siblings or half-siblings and therefore more likely to share heritable disease susceptibility factors and to have had the same prior exposure to GTFP, e.g. vertical disease transmission from the mother. The fact that turtles from all 4 clutches developed GTFP suggests that all 4 clutches were susceptible to disease. Transmission varied between fibropapilloma preparations however. The tumor extract prepared from donor 4 failed to induce fibropapillomas in any recipients. The infectious dose may have been too low in this extract or the tumors may have been at the wrong stage of development for infectious particle production. For example, bovine cutaneous fibropapillomas have a prepatent period during which productive papillomavirus infection cannot be detected (Olson et al. 1992). Exogenous factors may influence virus production and shedding in poikilothermic animals. For example, in Lucké renal adenocarcinoma of leopard frogs, which is caused by a herpesvirus, tumors are infectious only at the low temperatures required for the production and shedding of virus. Higher temperatures result in rapid growth and metastasis of noninfectious tumors (McKinnell 1984).

The development of detectable tumors in experimental turtles showed a lag time ranging from 15 to 43 wk. Although 2 sets of replicate experiments were conducted 8 wh apart, most tumors developed concurrently. An exogenous factor such as season or water temperature may have helped to synchronize tumor development. Temperature effects on the development and growth rates of neoplasia nave been weildocumented in poikilotherms (Asashima et al. 1985, Bowser et al. 1990). While our data are not conclusive, future studies should examine the effects of different environmental temperatures on the efficiency of disease transmission and tumor development. The time lag for development of tumors caused by oncogenic viruses may also be influenced by infectious dose (Beard et al. 1955). Presently we have no way to estimate the dose of infectious agent in our tumor extracts.

This study is the first to demonstrate the transmissibility of green turtle fibropapillomatosis. Efforts are underway to isolate the herpesvirus that we have identified in experimentally induced tumors and to test whether or not it causes GTFP. Work will continue to identify, isolate, and test other virions and viral genomic sequences from transmission positive fibropapilloma extracts to fulfill Koch's postulates for this disease. Identification and isolation of the etiologic agent will be important in developing the diagnostic assays necessary for studying the epizootiology of GTFP including monitoring green turtle populations for exposure, identifying reservoirs for the disease agent, and elucidating natural routes of transmission.

Acknowledgements. The authors thank Barbara Schroeder and Allen Foley (Marine Research Institute, Florida Department of Environmental Protection), Steve Johnson (University of Central Florida), Karen Bjorndal and Alan Bolten (Archie Carr Center for Sea Turtle Research, University of Florida), and Greg Erdos (Electron Microscopy Core, University of Florida) for their technical support. We also thank U.S. Air Corporation for transporting turtles between sites. This study was supported by grants from SAVE-A-TURTLE, Islamorada, Florida, a joint contract from The U.S. Fish and Wildlife Service, Department of the Interior and the Honolulu Laboratory, Southwest Fisheries Science Center, National Marine Fisheries Service, NOAA, Department of Commerce (RWO No. 96), and a training fellowship from the National Institutes of Health (National Center for Research Resources RR07001). This is Florida College of Veterinary Medicine Journal Series no. 392 . 


\section{LITERATURE CITED}

Aguirre AA, Balazs GH, Zimmerman B, Spraker TR (1994) Evaluation of Hawaiian green turtles (Chelonia mydas) for potential pathogens associated with fibropapillomas. J Wildl Dis 30:8-15

Asashima M, Oinuma T, Matsuyama H, Nagano M (1985) Effects of temperature on papilloma growth in the newt, Cynops pyrrhogaster. Cancer Res 45:1198-1205

Balazs GH (1991) Current status of fibropapillomas in the Hawaiian green turtle, Chelonia mydas. In: Balazs GH, Pooley SG (eds) Research plan for marine turtle fibropapilloma. US Dept Commerce, NOAA Tech Memo NMFS-SWFSC-156, p 47-57

Beard JW, Sharp DG, Eckert EA (1955) Tumor viruses. Adv Virus Res 3:149-197

Behbehani AM, Bolano CR, Kamitsuka PS, Wenner HA (1968) Yaba tumor virus. I. Studies on pathogenicity and immunity. Proc Soc exp Biol Med 129:556-561

Benjamin T, Vogt PK (1990) Cell transformation by viruses. In: Fields BN, Knipe DM, Chanock RM, Hirsch MS, Melnick JL, Monath TP, Roizman B (eds) Virology, 2nd edn, Vol 1. Raven Press, New York, p 317-367

Bowser PR, Martineau D, Wooster GA (1990) Effects of water temperature on experimental transmission of dermal sarcoma in fingerling walleyes Stizostedion vitreum. $\mathrm{J}$ aquat Anim Health 2:157-161

Brandsma JL, Xiao W (1993) Infectious virus replication in papillomas induced by molecularly cloned cottontail rabbit papillomavirus DNA. J Virol 67:567-571

Cohen FE, Pan K, Huang $Z$, Baldwin M, Fletterick RJ, Prusiner SB (1994) Structural clues to prion replication. Science 264:530-531

Cooper JE, Gschmeissner S, Holt PE (1982) Viral particles in a papilloma from a green lizard (Lacerta viridis). Lab Anim 16:12-13

Doane FW (1992) Electron microscopy and immunoelectron microscopy. In: Specter S, Lancz G (eds) Clinical virology manual, 2nd edn. Elsevier, New York, p 89-109

Ehrhart LM (1991) Fibropapillomas in green turtles of the Indian River lagoon, Florida: distribution over time and area. In: Balazs GH, Pooley SG (eds) Research plan for marine turtle fibropapilloma. US Dept Commerce, NOAA Tech Memo NMFS-SWFSC-156, p 59-61

Francis-Floyd R, Bolon B, Fraser W, Reed P (1993) Lip fibromas associated with retro-virus-like particles in angel fish J Am vet Med Ass 202:427-429

Gardner MB, Marx PA (1985) Simian acquired immunodeficiency syndrome. In: Klein G (ed) Advances in viral oncology, Vol 5, Viruses as the causative agents of naturally occurring tumors. Raven Press, New York, p 57-81

Graffi A, Bender E, Schramm T, Kuhn W, Schneiders F (1969) Induction of transmissible lymphomas in syrian hamsters by application of DNA from viral hamster papovavirusinduced tumors and by cell-free filtrates from human tumors. Proc Natl Acad Sci USA 64:1172-1175

Graffi A, Schramm T, Graffi I, Bierwolf D, Bender E (1968) Virus-associated skin tumors of the syrian hamster: preliminary note. J Natl Cancer Inst 40:867-873

Hardy WD Jr (1985) Feline retroviruses. In: Klein G (ed) Advances in viral oncology, Vol 5, Viruses as the causative agents of naturally occurring tumors. Raven Press, New York, p 1-34

Harshbarger JC (1984) Pseudoneoplasms in ectothermic animals. Natn Cancer Inst Monogr 65:251-273

Harshbarger JC (1991) Sea turtle fibropapilloma cases in the registry of tumors in lower animals. In: Balazs $\mathrm{GH}$, Pooley
SG (eds) Research plan for marine turtle fibropapilloma US Dept Commerce, NOAA Tech Memo NMFS-SWFSC. 156, p $63-70$

Hedrick RP, Groff JM, Okihiro MS, McDowell TS (1990) Herpesviruses detected in papillomatous skin growths of koi carp (Cyprinus carpio). J Wildl Dis 26:578-581

Hendrickson JR (1958) The green sea turtle, Chelonia mydas (Linn), in Malaya and Sarawak. Proc Zool Soc Lond 130: $455-535$

Henle W. Henle G (1985) Epstein-Barr virus and human malignancıes. In: Klein $G$ (ed) Advances in viral oncology, Vol 5, Viruses as the causative agents of naturally occurring tumors. Raven Press, New York, p 201-238

Herbst LH (1994) Fibropapillomatosis of marine turtles. A Rev Fish Dis $4: 389-425$

Herbst LH, Jacobson ER, Moretti R, Brown T, Klein PA, Greiner E (1994) Progress in the experimental transmission of green turtle fibropapillomatosis (Abstract). In: Schroeder BA, Witherington BE (eds) Proc 13th Ann Symp Sea Turtle Biology and Conservation. US Dept Commerce, NOAA Tech Memo NMFS-SEFSC-341, p 75

Hirth RSD, Wyand DS, Osborne AD, Burke CN (1969) Epidermal changes caused by squirrel pox-virus. J Am vet Med Ass 155:1120-1125

Hoffman W, Wells P (1991) Analysis of a fibropapilloma outbreak in captivity. In: Salmon M, Wyneken J (eds) Proc 11th Ann Workshop Sea Turtle Biology and Conservation, 26 February-2 March 1991. Jekyll Island, Georgia. US Dept Commerce, NOAA Tech Memo NMFS-SEFSC-302, p $56-58$

Howley PM (1983) The molecular biology of papillomavirus transformation. Am J Pathol 113:414-421

Howley PM (1990) Papillomavirinae and their replication. In: Fields BN, Knipe DM, Chanock RM, Hirsch MS, Melnick JL, Monath TP, Roizman B (eds) Virology, 2nd edn, Vol 2. Raven Press, New York, p 1625-1650

Ito Y, Evans CA (1961) Induction of tumors in domestic rabbits with nucleic acid preparations from partially purified Shope papilloma virus and from extracts of papillomas of domestic and cottontail rabbits. J exp Med 114:485-500

Jacobson ER (1981) Virus associated neoplasms in reptiles. In: Dawe CJ, Harshbarger JC, Kondo S, Sugimura T, Takayama $S$ (eds) Phyletic approaches to cancer. Japan Scientific Society Press, Tokyo, p 53-58

Jacobson ER, Buergelt C. Williams B, Harris RK (1991) Herpesvirus in cutaneous fibropapillomas of the green turtle Chelonia mydas. Dis aquat Org 12:1-6

Jacobson ER, Gaskin JM, Clubb S, Calderwood MB (1982) Papilloma-like virus infection in Bolivian side-neck turtles. J Am vet Med Ass 181:1325-1328

Jacobson ER, Gaskin JM, Roelke M. Greiner E, Allen J (1986a) Conjunctivitis, tracheitis, and pneumonia associated with herpesvrus infection in green sea turtles. J Am vet Med Ass 189:1020-1023

Jacobson ER, Mansell JL, Sundberg JP, Hajjar L, Reichmann ME, Ehrhart LM, Walsh M, Murru F (1989) Cutaneous fibropapillomas of green turtles (Chelonia mydas). J comp Pathol 101:39-52

Jacobson ER, Sundberg JP, Gaskin JM, Kollias GV, O'Banion MK (1986b) Cutaneous papillomas associated with a herpesvirus-like infection in a herd of captive african elephants. J Am vet Med Ass 189:1075-1078

Kimura T, Yoshimizu M, Tanaka M (1981a) Studies on a new virus (OMV) from Oncorhynchus masou, I. Characteristics and pathogenicity. Fish Pathol 15:143-147

Kimura T, Yoshimizu M, Tanaka M (1981b) Studies on a new virus (OMV) from Oncorhynchus masou, Il. Oncogenic 
nature. Fish Pathol 15:149-153

Kimura T, Yoshimizu M, Tanaka M (1981c) Fish viruses: tumor induction in Oncorhynchus keta by the herpesvirus. In: Dawe CJ, Harshbarger JC, Kondo S, Sugimura T, Takayama $S$ (eds) Phyletic approaches to cancer. Japan Scientifjc Society Press, Tokyo, p 59-68

Limpus CJ, Miller JD (1994) The occurrence of cutaneous fibropapillomas in marine turtles in Queensland. In: James $\mathrm{R}$ (eds) Proc Australian Marine Turtle Conservation Workshop, 14-17 November, 1990, Sea World Nara Resort, Gold Coast, Australia. Queensland Dept Environment and Heritage and the Australian Nature Conservation Agency, Brisbane, p $186-188$

Lucké B (1938) Studies on tumors in cold-blooded vertebrates. Annual report of the Tortugas Laboratory of the Carnegie Institute, 1937-38, Washington, DC, p 92-94

MacDonald D, Dutton P (1990) Fibropapillomas on sea turtles in San Diego Bay, Californía. Mar Turt Newsl 51:9-10

Martineau D, Renshaw RP, Williams JP, Cascy IW, Bowser PR (1991) A large unintegrated retrovirus DNA species present in a dermal tumor of walleye Stizostedion vitreum. Dis aquat Org 10:153-158

McKinnell RG (1984) Lucké tumor of frogs. In: Hoff GL, Frye FL, Jacobson ER (eds) Diseases of amphibians and reptiles. Plenum Press, New York, p 581-605

Norton TM, Jacobson ER, Sundberg JP (1990) Cutaneous fibropapillomas and renal myxofibroma in a green turtle, Chelonia mydas. J Wildl Dis 26:265-270

O'Connor DJ, Diters RN, Nielson SW (1980) Poxvirus and multiple tumors in an eastern gray squirrel. $J$ Am vet Med Ass 177:792-795

Olson C, Olson RO, Hubbard-Van Stelle S (1992) Variations of response of cattle to experimentally induced viral papillomatosis. I Am vet Med Ass 201:56-62

Owens DW, Ruiz GJ (1980) New methods of obtaining blood and cerebrospinal fluid from marine turtles. Herpetologica 36:17-20

Powell PC (1985) Marek's disease virus in the chicken. In: Klein $G$ (ed) Advances in viral oncology, Vol 5. Viruses as the causative agents of naturally occurring tumors. Raven Press, New York, p 103-127

Pulley LT, Shively JN (1973) Naturally occurring infectious fibroma in the domestic rabbit. Vet Pathol 10:509-519

Raynaud MM, Adrian M (1976) Lésions cutaneés à structure papillomateuse associées à des virus chez le lézard vert (Lacerta viridis Laur). C R S Acad Sci, Ser D (Paris) 283: 845-847

Rebel TP (1974) Sea turtles and the turtle industry of the West Indies, Florida, and the Gulf of Mexico. University of Miami Press, Coral Gables, FL

Responsible Subject Editor: P. Zwart, Utrecht, The Netherlands
Rebell G, Rywlin A, Haines H (1975) A herpesvirus-type agent associated with skin lesions of green turtles in aquaculture. Am J Vet Res 36:1221-1224

Sano T, Fukuda H, Furukawa M (1985) Herpesvirus cyprini: biological and oncogenic properties. Fish Pathol 20: $381-388$

Sano $T_{1}$ Fukuda $H$, Okamoto $N$, Kaneko F (1983) Yaname tumor virus: lethality and oncogenicity. Bull Jap Soc scient Fish 49:1159-1163

Schlumberger HG, Lucké B (1948) Tumors of fishes and amphibians, and reptiles. Cancer Res 8:657-753

Shope RE (1932) A filterable virus causing tumor-like condition in rabbits and its relationship to virus myxomatosum. $\mathrm{J}$ exp Med 56:803-822

Smith GM, Coates CW (1938) Fibro-epithelial growths of the skin in large marine turtles Chelonia mydas (L.). Zoologica 23:93-98

Smith GM, Coates CW (1939) The occurrence of trematode ova (Haplotrema constrictimin) (Leâred) in fibruepitheliâl tumours of the marine turtle Chelonia mydas (Linnaeus). Zoologica 24:379-382

Sundberg JP (1987) Papillomavirus infections in animaIs. In: Syrjanen K, Koss L, Gissman L (eds) Papillomaviruses and human disease. Springer-Verlag, Heidelberg, p $40-103$

Sundberg JP (1991) Etiologies of papillomas, fibropapillomas, fibromas, and squamous cell carcinomas in animals. In: Balazs GH, Pooley SG (eds) Research plan for marine turtle fibropapillomá. US Dept Commerce, NOAA Tech Memo NMFS-SWFSC-156, p 75-76

Teas W (1991) Sea turtle stranding and salvage network: green turtles, Chelonia mydas, and fibropapillomas. In: Balazs GH, Pooley SG (eds) Research plan for marine turthe fibropapilloma. US Dept Commerce, NOAA Tech Memo NMFS-SWFSC-156, p 89-93

Trimble JJ, Desrosiers RC (1991) Transformation by herpesvirus saimiri. Adv Cancer Res 56:335-355

Tsai CC, Tsai CC, Roodman ST, Woon MD (1990) Mesenchymal proliferative disorders (MPD) in simian AIDS associated with SRV-2 infection. J Med Prim 19:203-216

Yoshimizu M, Tanaka M, Kimura T (1987) Oncorhynchus masou virus (OMV): incidence of tumor development among experimentally infected salmonid species. Fish Pathol 22:7-10

Williams EH, Bunkley-Williams L, Peters EC, Pinto-Rodriguez B, Matos-Morales R, Mignucci-Giannoni AA, Hall KV, Rueda-Almonacid JV, Sybesma J, Bonnelly de Calventi I, Boulon RH (1994) An epizootic of cutaneous fibropapillomas in green turtles Chelonia mydas of the caribbean: part of a panzootic? J aquat Anim Health 6:70-78

Manuscript first received: July 8, 1994

Revised version accepted: October 10, 1994 